\title{
TOTAL NONDIALYZABLE SOLIDS (TNDS) IN HUMAN URINE. V. SUBFRACTIONATION OF THE ULTRAFILTRATE (UF-O) FRACTION *
}

\author{
By J. STANTON KING, JR. AND WILLIAM H. BOYCE \\ (From the Departments of Biochemistry and Urology, Bowman Gray School of Medicine, \\ Wake Forest College, Winston-Salem, N. C.)
}

(Submitted for publication May 21, 1959; accepted June 12, 1959)

A procedure has been reported (1) for the reproducible separation of the total nondialyzable solids (TNDS) of normal human urine into three primary fractions. The most abundant of the three fractions, designated UF-O, was separated from the other two by virtue of its passage through a collodion ultrafilter membrane. The overall chemical composition of fraction UF-O was described, but no further information was then available. Accordingly, we have devised a procedure for the separation of this material into subfractions. While these subfractions appear to be cleanly separated, they are all probably mixtures of various chemical compounds. The method yields consistent results and therefore seems to be a useful tool for the study of possible changes in physiological and pathological conditions, and as an intermediate step in the ultimate separation of the components of UF-O.

This report describes the procedure for the subfractionation of the UF-O and the results obtained with it, including the range of normal daily variation in the excretion of the subfractions and their overall chemical composition. Some pertinent ancillary information about the TNDS, acquired during these experiments, is also included.

\section{MATERIALS AND METHODS}

Subjects. Three 24 hour urine specimens were collected, with chloroform preservative, by each of 12 normally active, healthy subjects (eight male, four female). With one exception, they were the same subjects as in preceding reports of this series (1-3). Two male subjects were Negroes. The collections were made during the period September 15 to December 10.

As each day's specimen was completed, the process of dialysis and subsequent fractionation of the TNDS was begun, as previously described $(1,2)$.

Fractionation procedure. The subfractionation procedure for fraction UF-O depends essentially on three ob-

* Supported by Mary Reynolds Babcock Foundation and Public Health Service Grant A-259. servations. First, it had been noted (1) that the process of lyophilization effected a change in UF-O, manifested by the conversion of a large proportion of it to a dialyzable form. Preliminary experiments indicated that this was not the result of a purely random breakdown; instead, it seemed to be confined to some particular part of the UF-O. A further experiment showed that the lyophilization process alone, and not the fractionation per $s e$, was responsible for this dialyzability, since concentration of UF-O by rotary evaporation did not cause any portion of it to become dialyzable.

The second observation was that, of the portion which did not become dialyzable after lyophilization, part was precipitable by saturated basic lead acetate, by 5 per cent phosphotungstic acid in $2 \mathrm{~N} \mathrm{HCl}$, or by saturation with ammonium sulfate. These respective precipitates were, of course, not necessarily of the same constitution in each case. Trichloracetic, perchloric, tannic or picric acids gave no precipitate either with UF-O or with this material. Ammonium sulfate was chosen as the most convenient and innocuous precipitant for use in further study.

Thirdly, part of the dialyzable portion of UF-O could be precipitated with either alcohol or acetone, the latter being chosen for routine use.

The details of the procedure that was finally adopted were as follows. The lyophilized UF-O material for each subject, representing the three day urine collection, was mixed with $25 \mathrm{ml}$. of distilled water, placed in a Visking ${ }^{\circledR}$ cellophane dialysis sac $(0.75$ inch inflated diameter, 1.0625 inch flat width) ${ }^{1}$ leaving room for an increase in volume, and dialyzed 18 to 22 hours against $170 \mathrm{ml}$. cold distilled water. The dialysate, designated UF-1, was removed and recovered as a brittle, somewhat hygroscopic. yellow powder on lyophilization. Dialysis against several changes of cold water was continued for a further four days. This dialysate was discarded because of its impracticably large volume.

After dialysis, the dialysand was made to $\mathrm{pH} 4.0$ with acetic acid and centrifuged. ${ }^{2}$ The small, but very insoluble, centrifugate was washed and the washings added to the original supernate. The centrifugate was recovered on lyophilization as a gray or tan, nonhygroscopic, fluffy powder, designated UF-2.

1 The experiments of Craig, King and Stracher (4) indicate that the choice of tubing would affect the results, since dialyzability decreases with increasing tubing size.

2 All centrifugations were at $1,000 \times \mathrm{G}$ for 20 minutes. 
The supernatant, at room temperature, had an excess of ammonium sulfate added. The saturated solution was centrifuged or filtered ${ }^{3}$ after standing about one-half hour and the precipitate was washed with saturated aqueous ammonium sulfate; the washings were added to the supernate. The precipitate, designated UF-3, and the supernate, designated UF-4, were then separately dialyzed against cold water until free of ionic sulfate. Room for change of volume was allowed, so the cellophane would not be streched. UF-3 was a tan to dark brown, fluffy, nonhygroscopic powder on lyophilization; UF-4 was a cream-colored, fluffy, nonhygroscopic powder.

After weighing UF-1, $5 \mathrm{ml}$. of water was added and mixed. A small and very insoluble portion, designated UF-1A, was removed by centrifugation and washed with water. UF-1A was a pale gray or tan, nonhygroscopic powder on lyophilization. Five volumes of acetone were added to the supernate at room temperature. The resulting precipitate, designated UF-1B, was removed by centrifugation and washed with acetone. The soluble portion from the acetone precipitation, designated UF-1C, was checked for completeness of precipitation by further addition of acetone. The acetone was removed at 40 to $50^{\circ} \mathrm{C}$., by means of a rotary evaporator. The residue was finally lyophilized to a yellow-brown syrup or a highly hygroscopic tar.

A flow sheet summarizing the above procedure is presented in Figure 1.

The figures in Tables II and III for "number of analyses" represent analyses of material from that many different individuals, insofar as possible. Where necessary, pools of material from three to five individuals were used for analysis.

3 Eaton-Dikeman 42 mm. paper, No. 5268.
Analytical procedures. The methods used here have been previously described (1-3), except for the following additions.

A more convenient and equally accurate micromethod (5) was substituted in the nitrogen determination; a precision of 0.5 per cent or better was generally obtained among triplicate samples. The digestion was continued for one hour after the samples cleared.

Sialic acid was measured as before, but also by a more recently described procedure (6), except that $n$-octyl alcohol was substituted for amyl alcohol in the extraction and the final color was measured at $595 \mathrm{~m} \mu$.

A method for the estimation of those 6-desoxyhexoses (methylpentoses) present in UF-O was developed by modifying the usual anthrone procedure (7). It was observed that rhamnose and fucose developed their maximum color intensity with anthrone in a practically parallel fashion but faster, at a lower temperature, and have a somewhat different absorption maximum than did the hexoses present in UF-O. The color development of galactose and of fucose under the usual conditions and also under the conditions described below is illustrated in Figure 2, and is typical of the other hexoses (glucose, mannose) and 6-desoxyhexoses (rhamnose) in UF-O. The procedure was as follows. Solutions having 12.5, 25.0 and $50 \mu \mathrm{g}$. of rhamnose and of fucose per ml. were the standards. Two $\mathrm{ml}$. of cold standard and $4.0 \mathrm{ml}$. of freshly prepared, cold anthrone reagent $(200 \mathrm{mg}$. anthrone in $100 \mathrm{ml}$. sulfuric acid) were carefully mixed in a bath of crushed ice. The initial optical density, as compared with a water blank, was less than 0.04. Duplicate samples were similarly mixed. The tubes were allowed to come to room temperature, then placed in a water bath at $60^{\circ}$ for exactly six minutes, rapidly cooled in crushed ice, again al-

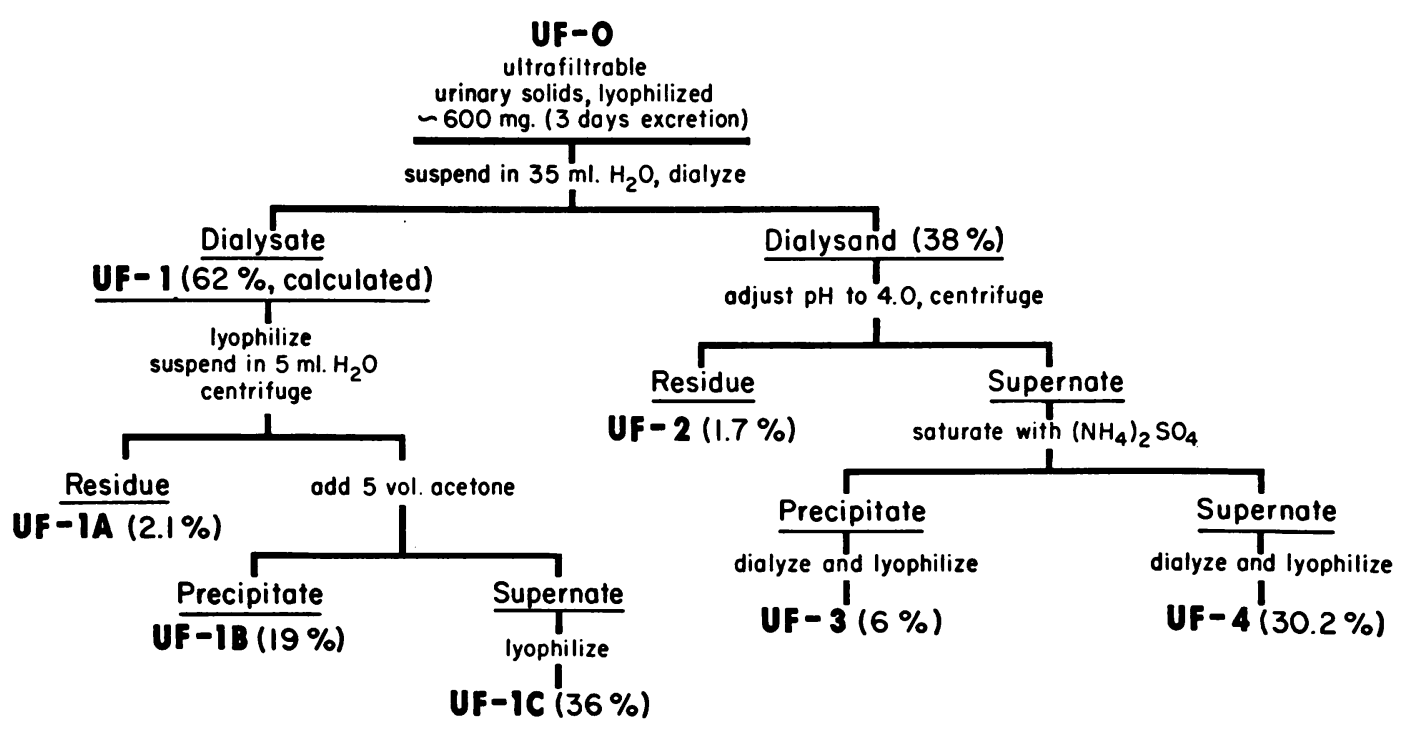

Fig. 1. Flow Sheet Summarizing the Procedure for the Subfractionation of UF-O Percentages represent average per cent of lyophilized UF-O found in each subfraction. 


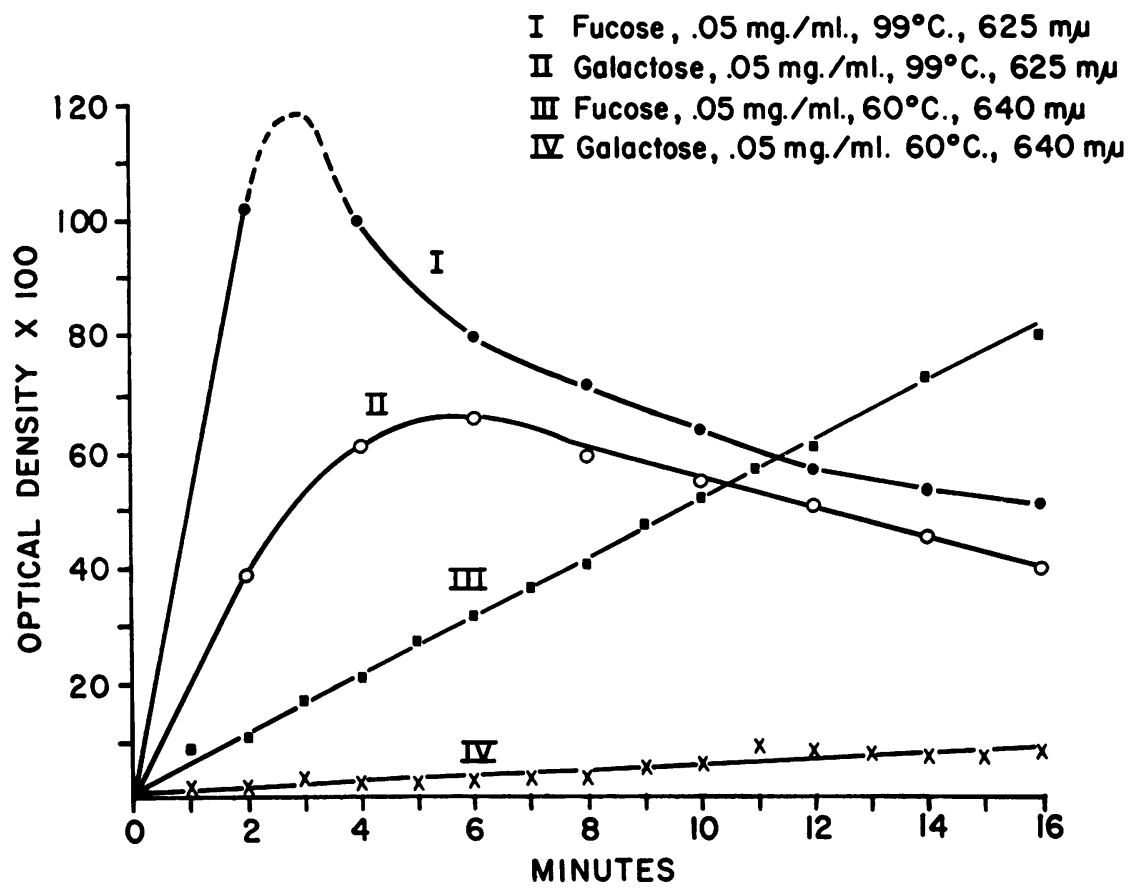

Fig. 2. Color Development of Galactose and Fucose with Anthrone Reagent Under Two Sets of Conditions

lowed to come to room temperature, and read vs. a waterreagent blank at $640 \mathrm{~m} \mu$. Under these conditions, the hexoses develop only about 10 to 15 per cent as much color as do the 6-desoxyhexoses. With respect to the present application, at least, the foregoing procedure is subject to much less interference than the cysteine-sulfuric acid reaction popularly used.

Electrophoresis was done as previously described (8), using a Spinco Model $\mathrm{H}$ electrophoresis-diffusion instrument.

\section{RESULTS}

\section{Excretion rates}

It may be seen (Table I) that the daily excretion of each of the fractions of UF-O is fairly constant for normal subjects. There were no apparent significant differences between older and younger, male and female, or white and Negro subjects. One subject, who had a common cold during the collection, showed a relatively increased UF-O (856 mg. per day). The increase was confined to the UF-1 material.

While only a portion of UF-1 was routinely recovered for each subject, experiments showed the analytical results obtained with this part to be representative of the total dialyzable material. An arithmetic extrapolation to the whole is therefore analytically valid. The portion of UF-1 actually recovered varied from 18 to 40 per cent (average $30.2 \pm 7.5)^{4}$ of the dialyzable part of UF-O,

4 Plus or minus values in the text are standard deviations.

TABLE I

Average daily excretion of subfractions of ultrafiltrable fraction (UF-O) of TNDS* by 12 subjects, in milligrams lyophilized dry weight

\begin{tabular}{lccccccc}
\hline \hline Fraction & UF-O & UF-1A $\dagger$ & UF-1B $\dagger$ & UF-1C $\dagger$ & UF-2 & UF-3 & UF-4 \\
\hline Mean & 196.8 & $2.6 \ddagger$ & 38.2 & $73.7 \ddagger$ & 3.4 & 11.9 & 59.5 \\
Range & $130-285$ & $2.14-3.42$ & $17.2-63.3$ & $70.2-77.5$ & $1.0-13.1$ & $8.8-17.7$ & $39.8-79.7$ \\
IS.D. & 50.9 & & 14.1 & & 3.33 & 2.51 & 13.21
\end{tabular}

* Total nondialyzable solids.

+ Values corrected for total (see text).

¥ Three pooled samples, each from three to five subjects. 


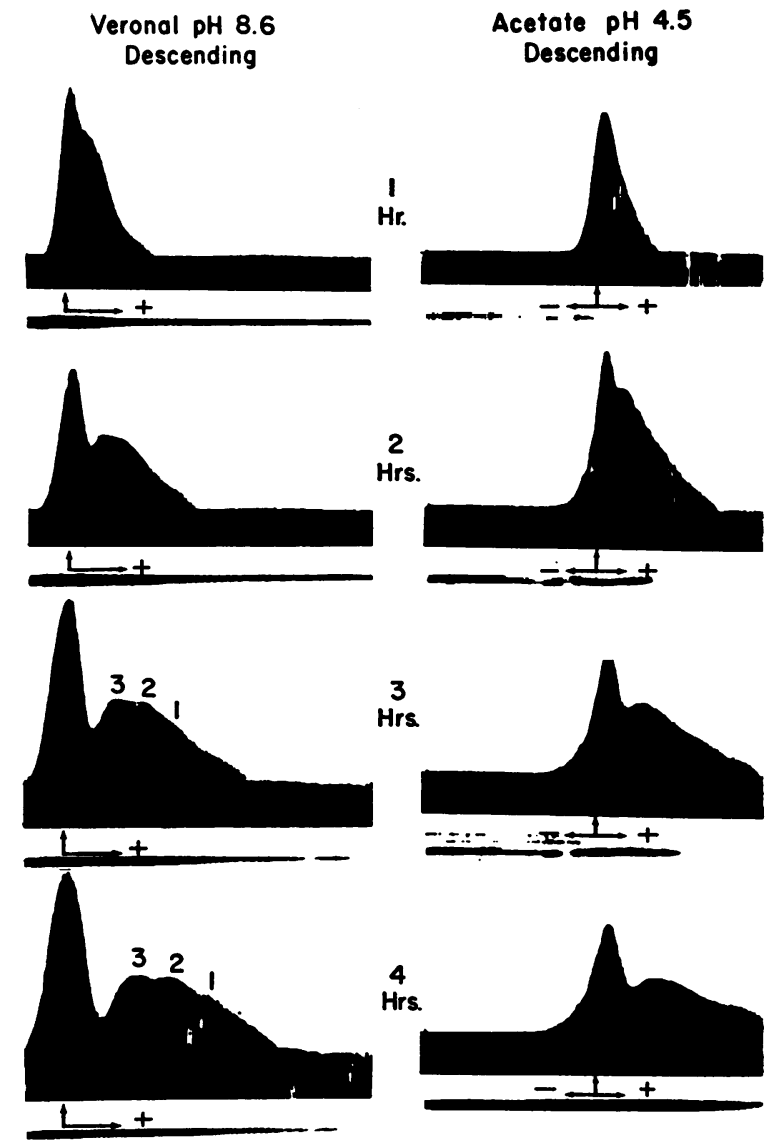

Fig. 3. Concentration Indicated Gradients of Fraction UF-4

Veronal buffer: ionic strength $0.1, \mathrm{pH} 8.6$, electropotential 6.4 volt $/ \mathrm{cm}$. Mobility of more clearly defined gradients 1,2 and 3 were, respectively, $-4.22,-2.98$ and $-2.04 \times 10^{-5} \mathrm{~cm}^{2} /$ volt sec. Acetate buffer: ionic strength $0.1, \mathrm{pH} 4.5$, electropotential $2.1 \mathrm{volt} / \mathrm{cm}$.

which in turn comprised 52 to 73 per cent (average $62 \pm 5$ ) of the UF-O as calculated by the difference between the starting weight and the sum of the combined weights of the nondialyzable fractions.

\section{Seasonal effect}

The other two primary fractions of TNDS, designated R-1 and RS-1 (1), were also measured during this study. Within experimental error, they gave the same values as have been obtained on other occasions and during other seasons of the year, respectively, 82.9 ( \pm 29.4$)$ and 51.3 ( \pm 20.7) $\mathrm{mg}$. per day. However, the average value for UF-O (Table I) was lower than that found in previous experiments, although the standard error of the mean was about the same as before. Data on the UF-O from three day specimens collected from eight subjects (four male, four female) during the period August 1 to October 20, 1957, were compared with data obtained in the same way from the same subjects during the period October 11 to December 10, 1958. The values averaged 258 and $204 \mathrm{mg}$. per day, respectively. This difference was statistically significant ( $\mathrm{p}<0.01>0.001$ ). Moreover, on plotting all data accumulated over a three year period on normal TNDS excretion (113 specimens) vs. date of measurement, there appeared to be a minimum in the excretion of TNDS reached during December and January, rising gradually to a maximum near the middle of September. The evidence indicates that the $\mathrm{UF}-\mathrm{O}$ is solely responsible for this change, although a more thorough study will be necessary for quantification. From the data given below, it can be computed that this alteration in the quantity of UF-O reflects an average decrease of approximately 20,14, 16 and $17 \mathrm{mg}$. per day in the respective excretion rates of hexose, sialic acid, protein and ash, as compared with the previously presented data (1). Which of the subfractions is responsible for this change has not yet been determined.

\section{Precipitation experiments}

The $\mathrm{pH}$ of maximum precipitation of $\mathrm{UF}-3$ was 2.7 as determined by a series of increments of hydrochloric acid to a solution at $\mathrm{pH}$ 8.6. UF-4 gave no precipitate over the $\mathrm{pH}$ range 2.3 to 10.5 .

\section{Electrophoresis}

Only one of the fractions, $\mathrm{UF}-4$, was suitable for electrophoresis by the moving boundary technique. Figure 3 illustrates typical patterns obtained with this material, which look much like patterns obtained with lyophilized UF-O.

\section{Serological tests}

Of the mammalian mucosubstances known at present, fraction UF-4 is most nearly like the blood group substances in analysis (9). A 20 per cent solution of UF-4 was mixed with human anti-A and anti-B serum. $A$ and $B$ human red 
blood cells were mixed with the corresponding antibody and suspected blood group substance. No decrease in red cell agglutination was noted as compared with anti-A and anti-B serum mixed with red blood cells.

\section{Analytical results}

The analytical results are summarized in Tables II and III. No sulfhydryl sulfur (i.e., less than 0.1 per cent) was found in UF-O. Total sulfur (Carius procedure) was 1.25 and 2.27 per cent in two samples analyzed. Most of this was sulfate sulfur, but a quantitative measurement was not made.

Hexosamine was not detectable in UF-O before hydrolysis, indicating that none of it is present as a nonacetylated end group.

A measure of the adequacy of the analytical data was obtained by adding the average values (Tables II and III) for the percentage of each constituent in each fraction. The two values obtained for hexose and for sialic acid, respectively, were first averaged; the nitrogen was corrected for the nitrogen present as hexosamine and sialic acid and then multiplied by the factor 6.25 as an estimate of the peptide. The following percentages resulted: UF-1A, 93.7; UF-1B, 104.4; UF-1C, 97.2; UF-2, 128; UF-3, 96.9 and UF-4, 99.2. Fraction UF-2 was analytically erratic from sample to sample and had no consistently reproducible composition.

\section{DISCUSSION}

At present, almost no information is available concerning the origin of the foregoing fractions, how many components are present in each of them, or their natural chemical state in urine.

The value of the subfractionation is analogous to that of a controlled partial hydrolysis of a protein, in that some less complex parts of the starting material are reproducibly separated. Information about these segments of UF-O can, perhaps, now be obtained more easily and reliably, and eventually interrelated.

It is obvious that lyophilization has caused some drastic alteration in some part of the UF-O, since it has become dialyzable. Whether this represents the partial disintegration of a component or components of UF-O through rupture of primary bonds, the release of a moiety or moieties held by secondary bonds, or both, is unknown.

TABLE II

Average glucide composition of subfractions of ultrafiltrable fraction (UF-O) of TNDS, expressed as per cent of lyophilized dry weight

\begin{tabular}{|c|c|c|c|c|c|c|c|c|c|}
\hline \multirow[b]{2}{*}{ Fraction } & \multicolumn{2}{|c|}{ Hexuronic acid } & \multirow[b]{2}{*}{ Hexosamine* } & \multicolumn{3}{|c|}{ Hexose } & \multirow[b]{2}{*}{$\begin{array}{l}\text { 6-Desoxy- } \\
\text { hexose }\end{array}$} & \multicolumn{2}{|c|}{ Sialic acid } \\
\hline & Naphth. & Carb. & & Anthrone & Orcinol & $\begin{array}{l}\text { Anth./ } \\
\text { Orc. }\end{array}$ & & $\begin{array}{l}\text { Diphenyl- } \\
\text { amine }\end{array}$ & Resorcinol \\
\hline $\begin{array}{l}\mathrm{UF}-1 \mathrm{~A} \\
\mathrm{n} \dagger\end{array}$ & $\begin{array}{c}0.25 \\
(2)\end{array}$ & & $\begin{array}{l}0.0 \\
(2)\end{array}$ & $\begin{array}{l}3.0 \\
(2)\end{array}$ & $\begin{array}{l}2.4 \\
(2)\end{array}$ & 1.25 & & $\begin{array}{l}0.0 \\
(2)\end{array}$ & $\begin{array}{l}0.0 \\
(2)\end{array}$ \\
\hline $\begin{array}{l}\text { UF-1B } \\
\text { n } \\
\text { S.E. mean }\end{array}$ & $\begin{array}{c}2.05 \\
(9) \\
0.25\end{array}$ & $\begin{array}{c}2.88 \\
(5) \\
0.45\end{array}$ & $\begin{array}{l}2.51 \\
(8) \\
0.23\end{array}$ & $\begin{array}{l}7.56 \\
(9) \\
0.67\end{array}$ & $\begin{array}{l}6.71 \\
(9) \\
0.61\end{array}$ & 1.13 & $\begin{array}{c}1.98 \\
(6) \\
0.04\end{array}$ & $\begin{array}{c}19.25 \\
(9) \\
2.29\end{array}$ & $\begin{array}{c}12.29 \\
(9) \\
1.86\end{array}$ \\
\hline$\underset{n}{U F-1 C}$ & $\begin{array}{l}1.84 \\
(2)\end{array}$ & $\begin{array}{c}4.47 \\
(3)\end{array}$ & $\begin{array}{r}15.0 \\
(2)\end{array}$ & $\begin{array}{l}5.2 \\
(2)\end{array}$ & $\begin{array}{l}6.6 \\
(2)\end{array}$ & 0.79 & & $\begin{array}{l}2.47 \\
(2)\end{array}$ & $\begin{array}{l}1 \\
(2)\end{array}$ \\
\hline $\begin{array}{l}\text { UF-2 } \\
\text { n } \\
\text { S.E. mean }\end{array}$ & $\begin{array}{l}0.26 \\
(4) \\
0.01\end{array}$ & & $\begin{array}{l}2.64 \\
(4) \\
0.52\end{array}$ & $\begin{array}{r}18.3 \\
(2)\end{array}$ & $\begin{array}{l}8.51 \\
(2)\end{array}$ & 2.15 & & $\begin{array}{l}0.0 \\
(4)\end{array}$ & $\begin{array}{l}0.0 \\
(4)\end{array}$ \\
\hline $\begin{array}{l}\text { UF-3 } \\
\text { n } \\
\text { S.E. mean }\end{array}$ & $\begin{array}{l}0.36 \\
(12) \\
0.02\end{array}$ & $\begin{array}{c}1.15 \\
(1)\end{array}$ & $\begin{array}{c}8.26 \\
(12) \\
0.30\end{array}$ & $\begin{array}{c}17.17 \\
(11) \\
0.84\end{array}$ & $\begin{array}{c}19.32 \\
(11) \\
1.32\end{array}$ & 0.92 & $\begin{array}{l}4.95 \\
(5) \\
0.18\end{array}$ & $\begin{array}{c}0.0 \\
(11)\end{array}$ & $\begin{array}{l}0.0 \\
(5)\end{array}$ \\
\hline $\begin{array}{l}\text { UF }-4 \\
\text { n } \\
\text { S.E. mean }\end{array}$ & $\begin{array}{l}0.38 \\
(12) \\
0.02\end{array}$ & $\begin{array}{l}4.28 \\
(4) \\
0.38\end{array}$ & $\begin{array}{c}20.63 \\
(11) \\
0.57\end{array}$ & $\begin{array}{c}30.78 \\
(11) \\
0.90\end{array}$ & $\begin{array}{c}21.89 \\
(11) \\
0.80\end{array}$ & 1.41 & $\begin{array}{c}7.69 \\
(7) \\
0.43\end{array}$ & $\begin{array}{c}8.45 \\
(11) \\
1.66\end{array}$ & $\begin{array}{l}2.54 \\
(7) \\
0.45\end{array}$ \\
\hline
\end{tabular}

* Expressed as glucosamine hydrochloride.

$\dagger \mathrm{n}=$ Number of analyses. 


\section{Glucides}

The major fractions of UF-O have a glucide content which is generally high and, in the case of fractions UF-3 and UF-4, is remarkably high. The results show that, in those fractions examined, one-third to one-fourth of the hexoses present are 6-desoxyhexoses. Preliminary paper chromatography after resin hydrolysis thus far has indicated $\mathrm{UF}-1 \mathrm{~B}$ and $\mathrm{UF}-1 \mathrm{C}$ to contain (in order of decreasing intensities of spot colors) galactose and rhamnose; UF-4 contained galactose, fucose and mannose. The apparent proportions of these sugars is consistent with the anthrone/orcinol ratios of the respective fractions (1).

The resorcinol method (6) for determining sialic acid gave results consistently lower than did the diphenylamine method. We are not prepared to discuss the reason for this difference, which has been observed also with other sialic acid-containing materials (10). It should be noted, however, that one of the two absorption maxima in the region 450 to $900 \mathrm{~m} \mu$ obtained by the diphenylamine method varies considerably in intensity from batch to batch of crystalline sialic acid standard. This is the maximum which may variably be found at 700 to $725 \mathrm{~m} \mu$. The reason for and nature of this variation, which may also occur in a long-refrigerated solution, is not completely clear. The other maximum, at $525 \mathrm{~m} \mu$, is the wave length at which measurements are routinely made, and has not varied significantly in wave length or extinction from batch to batch of standard. In UF-4, the absorption of the $700 \mathrm{~m} \mu$ maximum is relatively so large that the final color is visually violet-blue instead of violet and consequently so broad that it must also considerably increase the absorption at $525 \mathrm{~m} \mu$, creating a positive error in the estimation.

The interpretation of the results for hexuronic acid is clarified by the following observations. The hydrolytic conditions for the original naphthoresorcinol method did not sufficiently hydrolyze a commercial sample of chondroitin sulfate $(1 \mathrm{mg}$. per ml.) for a color reaction to be obtained with naphthoresorcinol (1). When the resin hydrolysis was tried instead, there was a partial but insufficient hydrolysis of chondroitin sulfate for accurate naphthoresorcinol determination. ${ }^{5}$ A pre-

5 A resin-hydrolyzed sample of commercial chondroitin sulfate containing $61 \mu \mathrm{g}$. hexuronic acid gave a pink, rather than a purple naphthoresorcinol reaction product, having a maximum at $517 \mathrm{~m} \mu$ and equivalent in optical density (at $565 \mathrm{~m} \mu$ ) to 56 per cent of the theoretical value.

TABLE III

Average inorganic and nitrogen content of subfractions of ultrafiltrable fraction (UF-O) of TNDS, expressed as per cent of lyophilized dry weight

\begin{tabular}{|c|c|c|c|c|c|}
\hline Fraction & Nitrogen & $\begin{array}{l}\text { "Bound" } \\
\text { water }\end{array}$ & Ash & $\mathrm{Ca} *$ & $\mathrm{P}^{*}$ \\
\hline $\begin{array}{l}\mathrm{UF}-1 \mathrm{~A} \\
\mathrm{n} \ddagger\end{array}$ & $\begin{array}{c}0.34 \dagger \\
(2)\end{array}$ & $\begin{array}{r}15.1 \\
(2)\end{array}$ & $\begin{array}{r}66.5 \\
(2)\end{array}$ & $\begin{array}{r}17.4 \\
(2)\end{array}$ & $\begin{array}{r}10.1 \\
(2)\end{array}$ \\
\hline $\begin{array}{l}\text { UF-1B } \\
\text { n } \\
\text { S.E. mean }\end{array}$ & $\begin{array}{l}5.41 \\
(9) \\
0.41\end{array}$ & $\begin{array}{l}8.96 \\
(5) \\
0.49\end{array}$ & $\begin{array}{c}40.16 \\
(5) \\
4.19\end{array}$ & $\begin{array}{c}12.36 \\
(5) \\
1.41\end{array}$ & $\begin{array}{l}3.12 \\
(5) \\
0.74\end{array}$ \\
\hline$\underset{\mathrm{n}}{\mathrm{UF}-\mathrm{IC}}$ & $\begin{array}{c}4.83 \\
(3)\end{array}$ & $\begin{array}{c}16.13 \\
(3)\end{array}$ & $\begin{array}{c}16.52 \\
(3)\end{array}$ & $\begin{array}{l}2.42 \\
(3)\end{array}$ & $\begin{array}{l}0.90 \\
(3)\end{array}$ \\
\hline $\begin{array}{l}\text { UF-2 } \\
\text { n } \\
\text { S.E. mean }\end{array}$ & $\begin{array}{c}5.98 \\
(4) \\
1.40\end{array}$ & $\begin{array}{r}13.7 \\
(2)\end{array}$ & $\begin{array}{r}62.1 \\
(3)\end{array}$ & $\begin{array}{c}13.00 \\
(3)\end{array}$ & $\begin{array}{l}8.4 \\
(2)\end{array}$ \\
\hline $\begin{array}{l}\text { UF-3 } \\
\text { n } \\
\text { S.E. mean }\end{array}$ & $\begin{array}{l}9.11 \\
(12) \\
0.42\end{array}$ & $\begin{array}{c}11.55 \\
(2)\end{array}$ & $\begin{array}{l}6.13 \\
(3)\end{array}$ & $\begin{array}{c}26.35 \\
(2)\end{array}$ & $\begin{array}{l}8.1 \\
(2)\end{array}$ \\
\hline $\begin{array}{l}\mathrm{UF}-4 \\
\text { n } \\
\text { S.E. mean }\end{array}$ & $\begin{array}{l}5.67 \\
(12) \\
0.39\end{array}$ & $\begin{array}{c}12.11 \\
(13) \\
1.46\end{array}$ & $\begin{array}{c}7.00 \\
(12) \\
0.63\end{array}$ & $\begin{array}{c}21.18 \\
(12) \\
1.77\end{array}$ & $\begin{array}{c}6.18 \\
(12) \\
0.62\end{array}$ \\
\hline
\end{tabular}

* Per cent of ash.

† Separate samples gave 0.32 and 0.35 per cent N. Because of high ash content, a third sample was run by Dumas procedure and gave 1.50 per cent $\mathrm{N}$.

$\ddagger \mathrm{n}=$ Number of analyses. 
liminary hydrolysis is not necessary for determining hexuronic acids with carbazole, but extraneous color interference is a serious problem, which is much reduced by resin hydrolysis. In general, the differences between the results obtained (Table I) with carbazole (and resin hydrolysis) and with naphthoresorcinol (and acid hydrolysis) appear to be primarily, if not completely, a consequence of positive hexose or other interference, which is incompletely corrected for by a no-carbazole blank. Thus, the fractions generally contain only "non-acid mucopolysaccharide hexuronic acid." ${ }^{\circ}$

Fraction UF-4 (and possibly UF-3, the ultimate distinction being a matter of judgment) is an exception; the differences obtained with the two methods appear too large relative to the interference to be entirely accounted for in this way. Moreover, a strongly carbazole-positive material, with very little interference, can be precipitated from this fraction with cetyltrimethylammonium bromide (11); carbazole positive material, together with considerable interfering material, can also be isolated by the apparently less selective glacial acetic acid precipitation followed by ethanol precipitation from solution in 3 per cent potassium hydroxide. These same solubility properties have, of course, been used in the isolation of chondroitin sulfate.

In fraction $\mathrm{UF}-4$, the result with resin hydrolysis and carbazole is therefore probably the most nearly accurate figure for "total hexuronic acid," while the acid hydrolysis and naphthoresorcinol method certainly provides the most nearly accurate figure for "non-acid mucopolysaccharide hexuronic acid," and indeed approximates the daily excretion rate reported for such material $(11,12)$, the remainder being present in the RS-1 fraction (1), which contains a relatively small amount of bound hexuronic acid in each of the two forms.

\section{Peptides}

It is noteworthy that fraction UF-1B was strongly ninhydrin positive (three minute boiling) for samples from some individuals, but negative for others. Fraction UF-1C was negative, or

${ }^{6}$ By "acid mucopolysaccharide" is intended chondroitin sulfate(s) (or chondromucoprotein), heparin and/or hyaluronic acid. only very weakly positive, in all. A positive ninhydrin test is generally indicative of free amino acids, hexosamine or short, simple peptides.

\section{Inorganic constituents}

In preceding reports $(1,2)$, it was stated that tests for phosphorus were negative prior to ashing. This observation was incorrect. A color sufficient to account for approximately all the phosphorus (as inorganic phosphate) is developed by the lyophilized, unashed UF-O.

The variations in content of ash, $\mathrm{Ca}$ and $\mathrm{P}$ among the fractions is noteworthy. It must be remembered that dialysis is an asymptotic process, however, and the most reasonable present explanation for the high ash contents of fractions $\mathrm{UF}-1 \mathrm{~A}$ and $\mathrm{UF}-2$ is that this represents some last traces of originally dialyzable (and reversibly bound) salts, which precipitated irreversibly on lyophilic concentration. The analytical inconsistency of UF-2 suggests that the organic portion probably was not originally bound to any considerable amount of this ash, but was present adventitiously as denatured material and/or traces of fraction $\mathrm{R}-1$ (1) which managed to pass the ultrafilter membrane.

\section{SUMMARY}

A method has been described for the separation of the ultrafiltrable fraction of the total nondialyzable solids of normal urine into six arbitrary but reproducible subfractions. The 24 hour excretion rates and the overall chemical composition of these six subfractions are presented.

\section{ACKNOWLEDGMENT}

The authors wish to acknowledge the technical assistance of Mrs. Phyllis Tilley. Dr. Glenn Watson and Dr. Peter Baram, Department of Microbiology, suggested the modification of the resorcinol procedure (6), and performed the tests for blood group substance activity, respectively.

\section{REFERENCES}

1. Boyce, W. H., King, J. S., Jr., Little, J. M., and Artom, C. Total nondialyzable solids (TNDS) in human urine. II. A method for reproducible fractionation. J. clin. Invest. 1958, 37, 1658.

2. King, J. S., Jr., Boyce, W. H., Little, J. M., and Artom, C. Total nondialyzable solids (TNDS) 
in human urine. I. The amount and composition of TNDS from normal subjects. J. clin. Invest. 1958, 37, 315.

3. King, J. S., Jr., Little, J. M., Boyce, W. H., and Artom, C. Total nondialyzable solids (TNDS) in human urine. III. A method for subfractionation of RS-1 solids. J. clin. Invest. 1959, 38, 1520.

4. Craig, L. C., King, T. P., and Stracher, A. Dialysis studies. II. Some experiments dealing with the problem of selectivity. J. Amer. chem. Soc. 1957, 79, 3729.

5. Lang, C. A. Simple microdetermination of Kjeldahl nitrogen in biological materials. Analyt. Chem. 1958, 30, 1692.

6. Svennerholm, L. Quantitative estimation of sialic acids. Biochim. biophys. Acta 1957, 24, 604.

7. Scott, T. A., Jr., and Melvin, E. H. Determination of dextran with anthrone. Analyt. Chem. 1953, 25, 1656.
8. Boyce, W. H., and King, J. S., Jr. Total nondialyzable solids (TNDS) in human urine. IV. Electrophoretic properties of RS-1 subfraction. J. clin. Invest. 1958, 38, 1525.

9. Bettelheim-Jevons, F. R. Protein-carbohydrate complexes in Advances in Protein Chemistry, C. B. Anfinsen, Jr., M. L. Anson, K. Baily and J. T. Edsall, Eds. New York, Academic Press Inc., 1958 , vol. 13 , p. 36.

10. Watson, R. G., Marinetti, G. V., and Scherp, H. W. The specific hapten of group C (group II a) meningococcus. II. Chemical nature. J. Immunol. 1958, 81, 337.

11. DiFerrante, N., and Rich, C. The determination of acid aminopolysaccharide in urine. J. Lab. clin. Med. 1956, 48, 491.

12. Kerby, G. P. The excretion of glucuronic acid and of acid mucopolysaccharides in normal human urine. J. clin. Invest. 1954, 33, 1168. 